\title{
Erratum to: Identification and optimization of tyrosine hydroxylase activity in Mucuna pruriens DC. var. utilis
}

\author{
Pratibha Mehta Luthra $\cdot$ Satendra Singh
}

Published online: 31 March 2010

(C) Springer-Verlag 2010

\section{Erratum to: Planta}

\section{DOI 10.1007/s00425-010-1140-y}

Author regrets the error in the figure legend 10. In the fifth line, the word polyclonal should read as monoclonal. The correct Fig. 10b legend is given below.

Immunoblot (lanes 1 and 2) of total proteins from leaves probed with the purified monoclonal rat tyrosine hydroxylase antibody reacted with a $55-\mathrm{kDa}$ protein band of tyrosine hydroxylase.

The online version of the original article can be found under doi:10.1007/s00425-010-1140-y.

P. M. Luthra ( $₫)$. S. Singh Medicinal Chemistry Division,

Dr B.R. Ambedkar Center for Biomedical Research,

University of Delhi, Delhi 110007, India

e-mail: pmluthra@acbr.du.ac.in; pmlsci@yahoo.com

S. Singh

e-mail: ssingh@acbr.du.ac.in 